\title{
Comparison of patients receiving salicylate before coronary artery surgery with patients not receiving in terms of postoperative mortality rates
}

B Ozcem, U Yetkin", M Bademci, M Akyuz, S Yazman, E Celik, N Karakas, I Yurekli, A Gurbuz

From 23rd World Congress of the World Society of Cardio-Thoracic Surgeons

Split, Croatia. 12-15 September 2013

\section{Background}

The aim of this study is to detect whether there is a significant difference between patients receiving $100 \mathrm{mg}$ enteric coated salicylate before coronary artery surgery with patients not receiving in terms of postoperative mortality rates.

\section{Methods}

Sixty one patients that underwent coronary bypass surgery between January 2011 and December 2011 at our clinic were investigated retrospectively. Sixty one $(80.3 \%)$ of them were operated on under cardiopulmonary bypass and $12(19.7 \%)$ were operated on beating heart. Thirty (49.2\%) of them were receivers of $100 \mathrm{mg}$ enteric coated salicylate and 31 (50.8\%) were non-receivers, divided into 2 groups. The mean age of salicylate receivers was 61.33 years whereas it was 57.71 years in the non-receivers.

\section{Results}

The mortality rate was $4.5 \%$ for cases receiving salicylate that underwent coronary surgery using cardiopulmonary bypass (CPB), and $3.7 \%$ for cases not receiving salicylate. No significant difference was seen ( $p>0.05)$. No mortality was seen among patients that underwent coronary surgery on beating heart.

\section{Conclusions}

In this study, we investigated the patient groups that underwent surgery in either method. Salicylate use did

\footnotetext{
* Correspondence: ufuk_yetkin@yahoo.fr

Department of Cardiovascular Surgery, Izmir Katip Celebi University Ataturk Training and Research Hospital, Izmir, Turkey
}

not cause any increase in mortality rate with no significant difference.

Published: 11 September 2013

\section{doi:10.1186/1749-8090-8-S1-P108}

Cite this article as: Ozcem et al.: Comparison of patients receiving

salicylate before coronary artery surgery with patients not receiving in terms of postoperative mortality rates. Journal of Cardiothoracic Surgery 2013 8(Suppl 1):P108.
Submit your next manuscript to BioMed Central and take full advantage of:

- Convenient online submission

- Thorough peer review

- No space constraints or color figure charges

- Immediate publication on acceptance

- Inclusion in PubMed, CAS, Scopus and Google Scholar

- Research which is freely available for redistribution

\section{() Biomed Central}

